\title{
Experiences from the "National Model United Nations" 2001
}

\author{
Andrea Theocharis - \\ -University of Marburg
}

This year for the first time a delegation from Marburg participated in NMUN in New York, representing Canada. 19 students (most of them are pol-sci students) prepared more than one year to improve their English, learn the Rules of procedure, learn and research about the UN and about Canada and of course to find sponsors for the project. But actually, what they had to spent most of their time on, was dealing with teamwork. Throughout the year the group had to handle with several inner conflicts and in endless discussions they had to practice their diplomatic capabilities in the forefront of the simulation. Unfortunatly one can not say, that these "negotiations" were always as open, peaceful and successful as one wishes UNnegotiations should have to be. But that's just sad reality isn't it?

As Canadian Governor in the Board of Governors of the Inter - American Development Bank

The National Model United Nations claims to be
the most realistic simulation of the United
Nations in the world. Every year more than 2500
students participate in the NMUN in New York,
which partly takes place inside the original UN-
buildings. For five days, the students simulate the
different bodies of the UN-framework (e.g.
Security Council, General Assembly, ECOSOC)
by using the original UN-Rules of procedure and
negotiating to formulate and pass resolutions on
various topics.

\section{The Simulation}

IADB - never heard about it? Me neither, before I decided to bring the Canadian perspective inside that body during the National Model United Nations this april in New York. The IADB is a multilateral development bank for Latin America and the Caribbean and has 47 member states. Next to American states several European countries, Israel and Japan are among them.

The issues discussed in the IADB during the simulation were: Combating Corruption in Latin America and the Caribbean and Rehabilitation after Natural Disasters. But soon it was clear that real substantial discussions were not necessary. Astonishing I recognized that many participants reduced negotiations on basic positions of their country. The session started with the opening of formal debate. During formal debate every Governor had the possibility to be set on the speakers list and once being in front as the next speaker, stressing in a limited time ones interests and priorities on the topic. These speeches were often used for diplomatic flourish without much substantial content but nevertheless with passion. (E.g. "Honourable Governors, I (or the State of Surinam) would (really) like to thank all of you for the amazing work you have done so far...) The more important and intensive discussions took place during suspensions of the meeting for the purpose of caucus.

Actually most of the time in session was spent in suspension of the meeting in New York in order to discuss more effective. Immediately the countries built blocs during informal debate. While the Latin American and the Caribbean states met in the corner of the conference room to talk about their strategy, the European countries discussed in the hall. The USA, Israel, Japan and Canada tried to negotiate with both blocs from the beginning on. The aim of the whole session was to formulate resolutions on the topic and get them passed in formal session. As in most committees, the Canadian part was a kind of an open-minded mediator. But unfortunately in the beginning the participants formed quite exclusive Plocs, so that the USA, Japan and me as Canada were not really able to talk to the member states, since the Latin American bloc and the European bloc as well simply refused to talk to us. They wanted to clear their positions first to ensure a strong common sense among them. So spontaneously we (USA, Japan and Canada) went for a coffee in diplomatic style, doing small talk about cultural differences, reassuring us our mutual good relations and things like that, knowing that if the other states would want our support for their ideas they would have to talk to us anyway. After dropping some hints in this directions discussions were more open in the end.

The draft resolutions were elaborated on the few Laptops brought by some students. In fact this gave the owner of the Laptop a little power and influence which was in my opinion not very good for the simulation process. During the drafting of resolutions everybody tried to bring his own interests into the text. If you weren't loud enough or stood not near to the Laptop owner you nearly had no chance. Only when we reached the second topic on the last day of sessions someone had the idea of asking every nation about their perspectives and priorities on the topic $\mathrm{X}$ and continuing with formulating common points. But in the end both topics did not lead to extremely controversial discussions and we were able to elaborate and pass resolutions that also had the support of Canada. 
Surprisingly on the $3^{\text {rd }}$ day of the conference two real representatives of the IADB joined our session and we had the possibility to ask questions whenever we wanted to during informal debate. The attendance of these "real IADB diplomats" was a great motivation and actually it had a very positive affect on the atmosphere of our negotiations.

\section{Saving the world, Manager qualities and the UN \\ A Résumé}

Acting as a diplomat, see how it is to represent the interests of a country, standing inside the UN-Headquarter in New York - on the whole great experiences for every participant.

So long, and what else? What do I take with me after these five days with 2500 student "future leaders", as we were called during the opening session? Now, some days later I try to keep the overview - why else does it make sense to take part in NMUN?

For me personally the main gain was the realization that the "diplomatic parquet" will not be my carrier perspective. Instead of representing, selling and carrying through (foreign)-interests as practiced in the model, I deem it more interesting to go into topics doing research.

If NMUN is was it claims to be, the most realistic model of the UN in the world, then the task of diplomats is reduced to transmitting national interests, which most of the time pursue mere national profit. It appears to me as if for this position the basic presupposition is not necessarily and by all means the ability of independent critical thinking. Not even extensive knowledge of the matter seems to be necessary. What is needed is what can be labelled as "manager qualities": leader personality, rhetorical capacity, the ability to prevail and convincing appearance. All these qualities can be read every week in the newspapers if one looks at vacancies of business enterprises.

But shouldn't an organisation like the United Nations also apply other standards? Shouldn't the "political world elite" that works together in the worlds biggest multinational organisation, at least officially pursuing to fight together for World Peace, the realization of Human Rights and the reduction of the North-South differences as declared goals, differ from and stand out against the "worlds economical elite", that simply pursues the maximum of profit for their own enterprises?!

During the time of my experiences with UN-models in Marburg, Hamburg and New York, unfortunately a discussion on the student level of

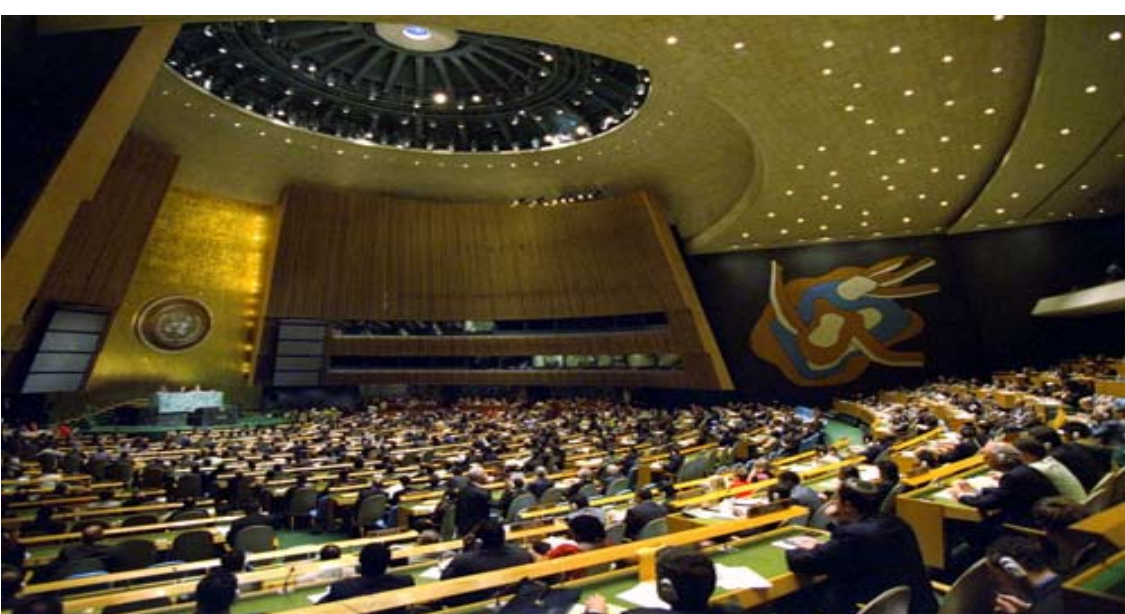

UN General Assembly

this kind did not take place; nor there was an evaluation at the end.

The idea of UN-simulations is in my opinion nevertheless a good one, because one can learn much about history, functions and structure of the UN as well as about the country one represents. Hope remains that in reality everyday life passes less "profile neurotically" as seen on NMUN level.

But even more then before, I deem the UN as an important and good element of international relations. What would happen, if this world forum would not exist? But it is no secret that it does not function really perfectly and just. That means the UN needs to stay in a process, having the ability to change and to improve into a more democratic and just direction. This can only start with criticism of the status quo and through its actors on state level as well as on the personnel level. Maybe I should keep my carrier perspective still open:-)? 